\title{
SIGHT RECORDS FOR THE YELLOW-BREASTED CHAT IN SOUTHWESTERN MANITOBA
}

\section{by John Lane and Wayne Miller, Brandon, Manitoba}

Although there appear to be no published records for the Yellowbreasted Chat (Icteria virens) in southwestern Manitoba, at least three sightings have been made in that part of the province during the past 50 years. In one June in the early 1920's, while tramping in the Brandon Hills south of Brandon, the senior author traced a loud medley to its source and saw his first Chat. On May 22, 1966, Miller noted a male of this species flitting through the bush on the west side of Sewell Lake. This bird was silent and soon disappeared.

On June 12, 1968, we shared a third sighting of the Yellow-breasted Chat along the Souris River west of Bunclody bridge. While engaged in a fruitless search for a pair of Orchard Orioles reported a week earlier by $\mathrm{Mr}$. W. Cowan and Mrs. H. Watson, we were attracted to an area just south of the river by repeated outbursts of unusual bird notes. We quickly spotted a male Yellow-breasted Chat singing from the top of a dead aspen which overlooked a small fen surrounded by a tangle of deciduous growth. He appeared to be singing on territory and we believed there was a good chance that a nest might be found. A cautious search of the underbrush resulted in two sightings of the female Chat.

On June 15 we returned to the area and found the male Chat still singing from the tip of the dead aspen and as we watched he gave a display of the famous flight song, in which he left his perch and towered to a considerable height, singing all the while. When he reached his highest point he hovered there until the song ended, then dropped straight down and regained his perch.

A third visit to the site on June 18 revealed no sign of the Chats, and subsequent searches were without result. One trip to the area in early June, 1969, in search of this species was also fruitless.

EDITOR'S NOTE: The Manitoba Museum of Man \& Nature has the following Yellowbreasted Chat records on file: Pilot Mound, May 29, 1929, Mrs. J. E. Hunt; Hillside Beach (Lake Winnipeg), June 27, 1933, F. J. Rogers; Whitemouth, August 13, 1933, V. Latta; Souris August 21, 1945. G. Willets; and Delta, July?, 1948 (reported to R. W. Sutton). So far as is known, a specimen is still lacking for the province.

\section{NINTH ANNUAL REPORT OF THE BRANDON JUNIORS' NESTBOX PROJECT}

by David Randall and John Lane, Brandon, Manitoba

The nesting season in 1969 showed a continuation of the remarkable increase in Mountain Bluebirds (Sialia currucoides) while Eastern Bluebirds (Sialia sialis) failed to make any appreciable gain over the 1968 totals reported to the Blue Jay by Brian Cutford (Blue Jay, 26:4). As usual, Mountain Bluebirds were back by mid-March, despite snowstorms and below-zero temperatures. By April 29 they were building nests, the first egg noted May 2. By such early starts, second broods are feasible and we estimate over 50 per cent of this species raise a second brood. Our latest date for vacating of the nest by Mountain fledglings was August 17. A few early Eastern Bluebirds had begun nesting by May 15 and the first egg was noted May 18, but mated pairs were still appearing locally in early June. Our latest date for vacating by young was August 25. Very few 
second broods appear to be attempted by this species in these northern regions.

Again this season we observed several unusual occurrences on our nestlines: nesthox \#516, on the C.P.R. just east of Sidney, was home for a litter of three Red Squirrels (Tamiasciurus hudsonicus), but the mother moved her family to safer quarters after we took the young from the nest to photograph them. Deer Mice (Peromyscus maniculatus) usually take over the nest boxes in the autumn, but in June, 1969, we found a Deer Mouse nest in nestbox \#544, which only a week earlier had been in the possession of a pair of Eastern Bluebirds. Three bluebird eggs were found intact under the mouse nest. Nestbox \#88, smashed to the ground by vandals, was occupied in this unusual position by a pair of Mountain Bluebirds and a set of five eggs laid. We replaced the nest atop a fencepost, but were obliged to leave it on its side so as not to spill the eggs. The family was safely raised.

On at least six occasions this year we found mated pairs of Mountain Bluebirds quietly perched on the high wire along a road, with no possible nest available. As soon as we took a nestbox from the car they showed an excited interest, and in every case the nest was scarcely nailed up before the male was at the entrance. Is it possible that these are locally-raised birds, with no instinct to go farther north in spring migration?

Starlings (Sturnus vulgaris) which have never been an important statistic in our nestbox totals, showed a marked increase this season, nine nestlings being listed. The last three starling nests found held families of dead young. Possibly this species is finding it difficult to cope with natural enemies in the wild and the parent birds are falling victims to predators while food-hunting for their young.

During the Easter vacation, 1969, we ran a new nestline north from Brandon, then east past Minnedosa and throussh Neepawa to Gladstone, then south to Austin on Highway No.1. A total of 100 nest boxes was set out and we later listed nine Mountain and three Eastern Bluebird nestings, which is an excellent start for a new line. This brings our total of nestboxes to 2100 , but we estimate that 100 of these are no longer active for one reason or other.

\section{Nesting totals for 1969}

Mountain Bluebirds (first broods)

Eastern Bluebirds (first broods)

Tree Swallows (estimated) ....... 1200

House Wrens ............................. 25

House Sparrows ......................... 20

Starling's .................................. 9

Deer Mice .................................. 35

Red Squirrel ............................ 1

\section{RED-HEADED WOODPECKER IN THE KANANASKIS VALLEY}

by William J. Merilees, Biology Department, Selkirk College, Castlegar, B.C.

One mile south of the Trans-Canada Highway on the Kananaskis to Coleman Forestry Road one Red-headed Woodpecker was seen on June 27, 1969. The bird, in full adult plumage, was sitting on a roadside fence post. No other individuals of this species were seen, though a brief search was made.

Salt (The birds of Alberta, second edition, 1966) gives the closest record as 20 miles west of Turner Valley, approximately 30 miles south southeast. Although this not an exceptional record, it is worth documenting as the range and status of this species may be changing.

\section{APOLOGIES!}

We are sorry that we had to raise the membership fee and we hope you won't think of dropping the Blue Jay. Use tear-out page and renew promptly and urge others to join us. 